\title{
Toxicity and biochemical efficacy of six essential oils against Tribolium confusum (du val) (Coleoptera: Tenebrionidae)
}

\author{
Mona F. Abd El-Aziz and Yasser. A. El-Sayed \\ Entomology Department-Faculty of Science- Benha University- Egypt.
}

\begin{abstract}
Six essential oils extracted from garlic (Allium sativum), mint (Mentha piperitaa), basil (Ocimum basilicum), thyme (Thymus vulgaris), sesame (Sesamum Indicume) and chamomile (Chamaemelum nobile) were tested for both repellency and toxicity against the confused flour beetle, Tribolium confusum adults and last larval instar. Two kinds of repellency bioassays were performed by using filter paper tests and treated kernels. The toxicological bioassay was performed by topical application. The results showed that the tested oils were highly repellent to the adult insect compared to the larvae. By contrast, the toxicological bioassay showed that larvae were more susceptible to tested essential oils than the adults. Effects of essential oils on five detoxification enzymes were also investigated. A reduction in total activities of the major detoxification enzymes in treated larvae was also observed.
\end{abstract}

Key words: Essential oils; Tribolium confusum; Repellency; Detoxification Enzymes.

\section{INTRODUCTION}

About $10-30 \%$ of grains produced worldwide are lost every year due to insect and rodent damage (White, 1995). The confused flour beetle, Tribolium confusum Du Val is one of the most serious pests of stored products worldwide. It can feed and develop in an extremely large variety of foodstuffs and it is a highly important pest in cereal products. Although, it develops well on broken grain kernels or processed grain products, particularly wheat flour, this species is also able to infest whole kernels (Aitken, 1975). Moreover, this species is resistant to many residual pesticides and fumigants used for stored-product protection (Zettler, 1991).

Essential oils of botanical origin and their major components, often their various monoterpenoids, have attracted attention in recent years as potential pest control agents due to their insecticidal, repellent and/or antifeedant properties (Amos et al., 1974; Grundy and Still, 1985; Shaaya et al., 1997; Lee et al., 2003; Ketoh et al., 2005, Rozman et al., 2007 and Cosimi, et al., 2009). Their lipophilic nature facilitates their interference with basic metabolic, biochemical, physiological and behavioral functions of insects (Nishimura, 2001). They have the potential to be ovicides, fumigants, insect growth regulators and insecticides against various insect species (Shaaya et al., 1997).

Many natural plant compounds and microorganisms used in the control of insect pests are known to affect the enzymatic profiles (Nathan, et al., 2005). Cytochrome P450 monooxygenases (CYPs), glutathione-S-transferases (GSTs) and esterases (ESTs) are three major detoxifying enzymes in most organisms. At least one of them is involved in detoxification of insecticides in insects (Bull, 1981). P450 enzymes (mixed function oxidases -MFO-, cytochrome P450 monooxygenases), one of the most important enzyme systems involved in insecticide detoxification or 
activation, are a complex family found in most organisms (Zhou and Huang ., 2002). In insects, the diverse functions of P450 enzymes range from the synthesis and degradation of ecdysteroids and juvenile hormones to the xenobiotics metabolism (Feyereisen, 2005). Insect GSTs have been implicated in resistance to insecticides, organophosphorous and pyrethroid, through direct insecticide metabolism (Wei et $a l ., 2001)$ or by protecting against secondary toxic effects, such as increases in lipid peroxidation, induced by insecticide exposure (Dou et al., 2009). A member of the esterase cluster probably plays a role in the detoxifcation of xenobiotic esters. (Gacar and Tasksn, 2009). Alkaline phosphatase (ALP) is a brush border membrane marker enzyme and is especially active in tissues with active membrane transport, such as intestinal epithelial cells (Etebari and Matindoost, 2004a), Malpighian tubules (Etebari and Matindoost, 2004b) and hemolymph (Etebari et al., 2007).

This study investigates six essential oils with possible insecticidal activity for their repellent and toxic efficacy against the confused flour beetle, Tribolium confusum DuVal (Coleoptera: Tenebrionidae). We have investigated also their biochemical effects against five detoxification enzymes of last larval instar.

\section{MATERIALS AND METHODS}

\section{Essential Oils:}

Essential oils from different families were used, garlic - Allium sativum(Alliaceae), mint -Mentha piperitaa- (Lamiaceae)), basil- Ocimum basilicum(Lamiaceae), thyme-Thymus vulgaris- (Lamiaceae), sesame-Sesamum Indicume(Pedaliaceae) and chamomile -Chamaemelum nobile-(Asteraceae). Essential oils were purchased from El-captain Company (CAP. PHARM., Egypt) for extracting natural oils, herbs and cosmetics, Cairo, Egypt.

\section{Tested insects.}

Cultures of the confused flour beetle, Tribolium confusum, were maintained in our laboratory over 2 years without exposure to insecticides and reared on wheat flour mixed with yeast (10: $1, \mathrm{w} / \mathrm{w})$. Insect rearing and all experimental procedures were carried out at $25 \pm 1{ }^{\circ} \mathrm{C}$ and $65 \%$ R.H. and a 12: 12 light: dark photoperiod.

\section{Repellency tests on filter paper}

The repellent effects of the different essential oils against $T$. confusum adults and last larval instar $\left(7^{\text {th }}\right.$ instar) were evaluated using the area preference method (McDonald et al., 1970). Essential oils in different doses were applied on filter paper (9 $\mathrm{cm}$ diameter) cut in half. Tested solutions were prepared by diluting 1, 0.5, 0.2, 0.1 and $0.05 \mathrm{ml}$, of each essential oil in $1 \mathrm{ml}$ acetone. 1001 of each solution was uniformly applied to a half-filter paper disc using a micropipette. The other half filter paper was treated with 1001 of acetone alone and used as control. All experiments and control dried for 10 minutes. Fifteen unsexed newly emerged adults or $7^{\text {th }}$ larval instars were put into each Petri dish. Petri dishes were subsequently covered. The treatments were replicated 3 times and the number of insects on the two half paper disks was recorded after 24 hours from the beginning of the test.

\section{Repellency tests on kernels}

The goal of this experiment was to mimic storage conditions, determining if tested oils is repellent or attractive to grain insect pests when directly applied on kernels. These assays were performed on adults and last larval instar, adapting the methodology suggested by Mohan and Fields (2002). The apparatus necessary to run the experiment consisted of two identical plastic cups (upper diameter $8 \mathrm{~cm}$ and lower diameter $5 \mathrm{~cm}$ ), one inside the other, the lower cup was transparent. Five holes ( 2 and 
$1 \mathrm{~mm}$ for adults and larvae, respectively) were made in the bottom of the upper cup. About $100 \mathrm{gm}$ of wheat kernels were treated with $0.25,0.01$ and $0.001 \mathrm{ml}$ of oil solutions dissolved in $1 \mathrm{ml}$ of acetone and placed in the perforated container, while the lower container was empty. The control was run treating the kernels with only acetone. All experiments and control dried for 20 minutes. Fifteen of newly emerged unsexed adults and $7^{\text {th }}$ larval instars of $T$. confusum were placed on the grains. The upper cup was covered with black tape to exclude light from the inside. Three replicates for each dosage were performed and the distribution of insects between the two containers was checked after $24 \mathrm{~h}$ of application.

\section{Toxicological assay by topical application:}

To assess the toxic efficacy of different essential oils extracts on adults and last larval instar of Tribolium confusum, 10 insects were put into each Petri dish (three replicate / concentration) on filter paper disc. Tested essential oils with different doses (1, $0.5,0.2,0.1$ and $0.05 \mathrm{ml}$ were dissolved in $1 \mathrm{ml}$ of acetone and applied topically on adults and last larval instar ( 1 and $0.5 \mu \mathrm{l}$ /each adult and larva, respectively) by using a micropipette. Control treatments were performed by topical application of 1 or 0.51 of acetone only per each adult and larva, respectively. Percentage of insect mortality was recorded after 48 hours.

\section{Detoxification enzyme assays:}

Effect of essential oils on the activities of five detoxification enzymes [alpha esterases ( $\alpha$-esterases); beta esterases ( $\beta$-esterases); Glutathione S-transferase (GST); mixed function oxidase (MFO) and alkaline phosphatase (ALP)] were measured. Newly moulted $7^{\text {th }}$ larval instars (60 larvae/treated) were treated topically with $\mathrm{LD}_{50}$ of test essential oils for $48 \mathrm{hrs}$. Another group of larvae were treated only with acetone and used as a control. $\alpha$-esterases and $\beta$-esterases were determined according to Van Asperen (I962) using $\alpha$-naphthyl acetate or $\beta$-naphthyl acetate as substrates, respectively. GST catalyzes the conjugation of reduced glutathione $(\mathrm{GSH})$ with 1-chloro 2,4dinitrobenzene(CDNB) via the -SH group of glutathione. The conjugate, S-(2,4-dinitrophenyl)-L-glutathione could be detected as described by the method of Habig et al., (I974). p-nitroanisole o-demthylation was assayed to determine MFO activity according to the method of Hansen and Hodgson (1971) with slight modification. ALP was determined according to the method described by Powel and Smith (1954) using disodium phenyl phosphate as substrate.

\section{Statistical analysis}

Percentage repellency (PR) values were computed as follows:

$\mathrm{PR}=\left[\left(\mathrm{N}_{\mathrm{c}}-\mathrm{N}_{\mathrm{t}}\right) /\left(\mathrm{N}_{\mathrm{c}}+\mathrm{N}_{\mathrm{t}}\right)\right] 100$.

Where $\mathrm{Nc}=$ number of insects in control test; $\mathrm{Nt}=$ number of insects in treated test (Hassanal et al., 1990). The mean repellency value of each essential oil was calculated and assigned to repellency classes (Juliana and $\mathrm{Su}, 1983$ ) from 0 to $\mathrm{V}$ : class 0 (PR $<0.1 \%)$, class I $(\mathrm{PR}=0.1-20 \%)$, class II $(\mathrm{PR}=20.1-40 \%)$, class III $(40.1-60 \%)$, class IV (60.1-80\%), class V (80.1-100\%). Percentage mortality was calculated for each treatment using the formula proposed by Abbott (1925). Probit analysis (Finney, 1971) was used to estimate $\mathrm{LC}_{50}$ and $\mathrm{LC}_{95}$ values. The differences in mean activities among detoxification enzymes were determined via one way analysis of variance (ANOVA) at $(\mathrm{P}<0.01)$ by Duncan's multiple range test.

\section{RESULTS}

\section{Repellency tests on filter paper:}

The average repellency values for the tested oils on adults and larvae of $T$. confusum after $24 \mathrm{~h}$ were tabulated in Table (1). The results showed that there was no variation in the repellent effects of the test oils on adults, the oils were highly 
repellent to the adult insect ( $\mathrm{PR}>70 \%$ ) compared to the larvae that had moderate repellency effect (PR $<61.1$ and $64.73 \%$ ) for thyme and basil, respectively and significantly lower effect for other oils (PR> 60.1).

Table (1): Repellent effects of six different essential oils to Tribolium confusum adults and last larval instar after $24 \mathrm{~h}$ of exposure in the filter paper test.

\begin{tabular}{|c|cc|cc|}
\hline \multirow{2}{*}{ Essential Oils* } & \multicolumn{4}{|c|}{ \%Mean Repellency and Repellency Class } \\
\cline { 2 - 5 } & Adult & $\begin{array}{c}\text { Repellency } \\
\text { Class }\end{array}$ & Larvae & Repellency class \\
\hline Thyme & $91.56 \pm 3.6109$ & V & $61.10 \pm 5.33$ & IV \\
\hline Basil & $80.88 \pm 11.75$ & V & $64.73 \pm 10.67$ & IV \\
\hline Mint & $72.24 \pm 16.15$ & IV & $58.70 \pm 6.2$ & III \\
\hline Garlic & $80.42 \pm 10.78$ & V & $56.89 \pm 2.00$ & III \\
\hline Chamomile & $73.88 \pm 2.91$ & IV & $62.90 \pm 6.34$ & IV \\
\hline Sesame & $88.88 \pm 2.45$ & V & $57.06 \pm 4.57$ & III \\
\hline
\end{tabular}

*Tested solutions were prepared by diluting $1,0.5,0.2,0.1$ and $0.05 \mathrm{ml}$, of each essential oil in $1 \mathrm{ml}$ acetone. 1001 of each solution was uniformly applied to a half-filter paper.

\section{Repellency Tests on Kernels:}

In the cup bioassay tests (Table 2) the moderate level of repellency was observed after $24 \mathrm{hrs}$ of exposure of adult to thyme oils $(\mathrm{PR}=68.67 \%)$. Other oils had lower repellency effect on adults (PR $<60.1 \%$ ). All tested oils attained very low repellency effect against larvae.

Table (2): Repellent effects of six different essential oils to Tribolium confusum adults and last larval instar after $24 \mathrm{~h}$ of exposure in the kernels test.

\begin{tabular}{|c|cc|cc|}
\hline \multirow{2}{*}{ Essential Oils* } & \multicolumn{4}{|c|}{ \%Mean Repellency and Repellency Class } \\
\cline { 2 - 5 } & Adult & Repellency class & Larvae & Repellency class \\
\hline Thyme & $68.67 \pm 5.93$ & IV & $21.1 \pm 4.92$ & II \\
\hline Basil & $48.87 \pm 2.94$ & III & $22.23 \pm 6.19$ & II \\
\hline \multirow{2}{*}{ Mint } & $31.2 \pm 1.05$ & II & $11.1 \pm 4.85$ & I \\
\hline Garlic & $59.8 \pm 6.5$ & III & $16.65 \pm 3.35$ & II \\
\hline Chamomile & $46.7 \pm 10$ & III & $11.1 \pm 6.18$ & II \\
\hline Sesame & $56.53 \pm 7.03$ & III & $15.53 \pm 2.23$ & II \\
\hline
\end{tabular}

*About $100 \mathrm{gm}$ of wheat kernels were treated with $0.25,0.01$ and $0.001 \mathrm{ml}$ of oil solutions dissolved in $1 \mathrm{ml}$ of acetone

\section{Toxicological assay by topical application:}

The percentage mortality of $T$. confusum adult and last larval instar after 48 hours of exposure to essential oils increased with the increasing oil dose. Thyme oil was able to induce $100 \%$ mortality of adults within 48 hours of exposure (Figure 1) followed by chamomile $(97.7 \%)$, basil $(95.7 \%)$ at dose $1 \mathrm{ml}(1 \mu \mathrm{l} /$ insect). Sesame oil induced the lowest mortality percent $(73.7 \%)$ at dose $1 \mathrm{ml}$ and (18.3) at dose $0.05 \mathrm{ml}$.

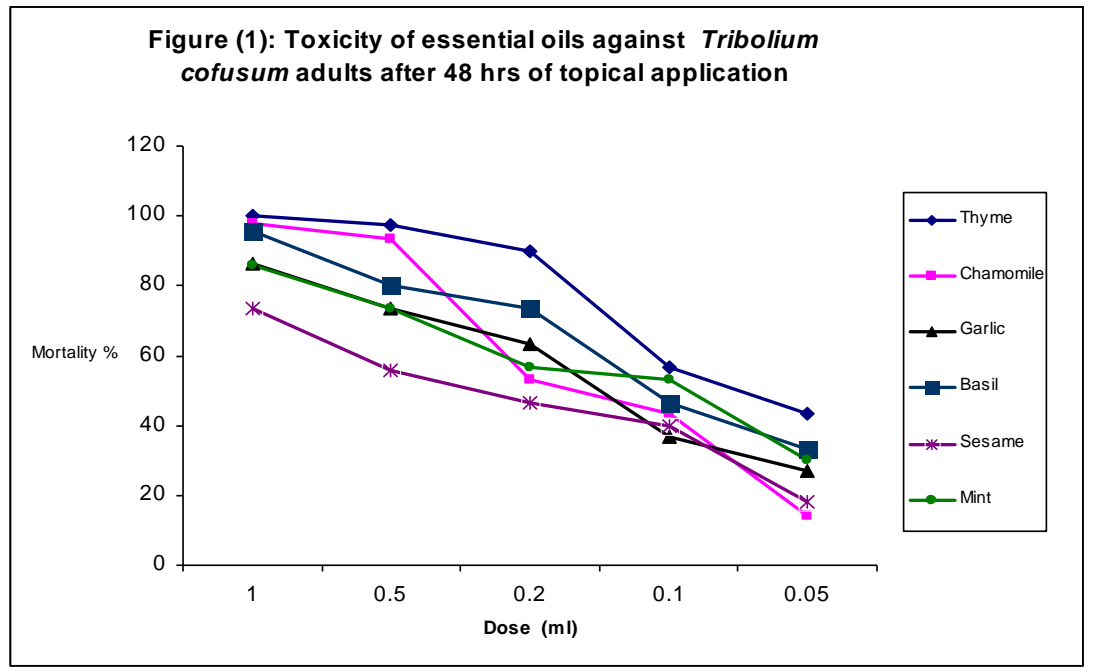


After 48 hrs of topical application to tested oils on last larval stage the dosage of $1 \mathrm{ml}(0.5 \mu \mathrm{l} /$ insect $)$ of thyme, basil and chamomile induced $100 \%$ of mortality (Figure 2). Also sesame oil induced the lowest effect against larvae, it induced 93.3 and $10.5 \%$ at doses 1 and $0.05 \mathrm{ml}$, respectively.

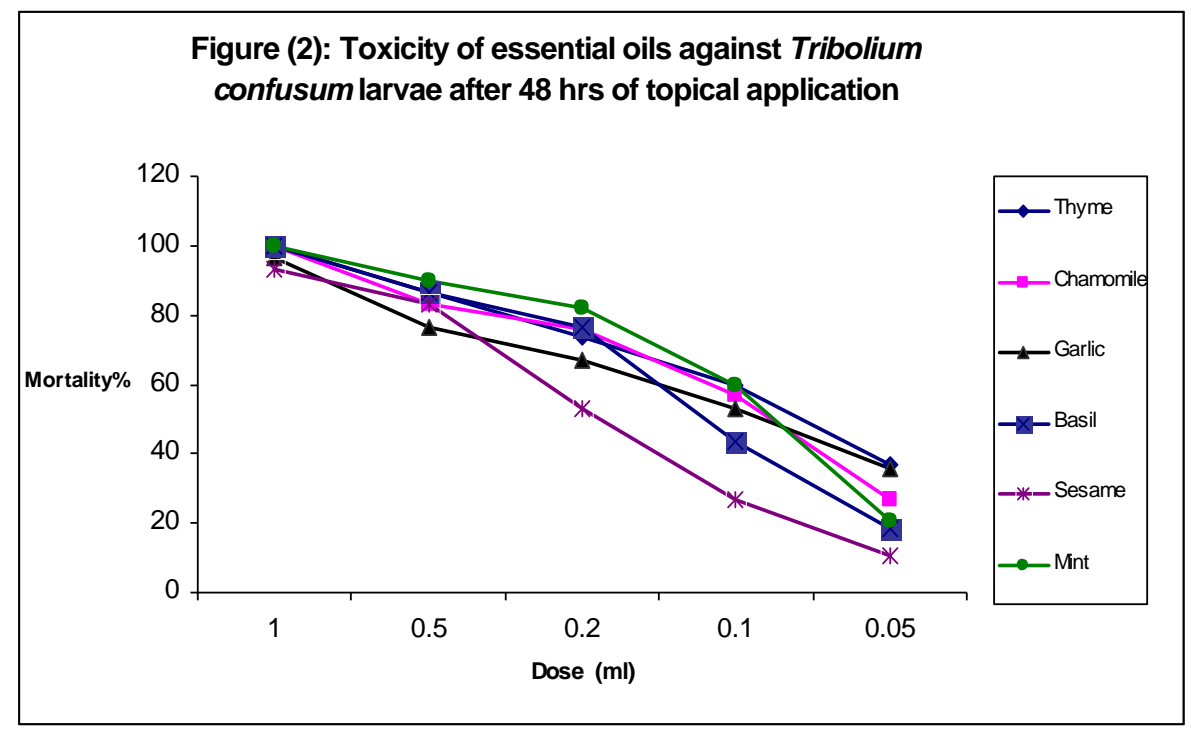

Probit analyses of the obtained data (Table 3) confirmed that thyme oil was most toxic for adults $\left(\mathrm{LD}_{50}=0.06 \mathrm{ml}\right.$ and $\left.\mathrm{LD}_{90}=0.39 \mathrm{ml}\right)$ while sesame oil showed the lowest toxic effect $\left(\mathrm{LD}_{50}=0.32 \mathrm{ml}\right.$ and $\left.\mathrm{LD}_{90}=2.2 \mathrm{ml}\right)$. Last larval instar was more sensitive to the tested oils. All tested essential oils showed approximate effects against larvae. In most cases the $\mathrm{LD}_{50}$ and $\mathrm{LD}_{90}$ were lower than those of adults.

Table (3): $\mathrm{LD}_{50}$ and $\mathrm{LD}_{95}$ calculated for mortality of $T$. confusum adults and last larval instar exposed to essential oils by topical application for 48 hours.

\begin{tabular}{|c|cc|cc|}
\hline \multirow{2}{*}{ Essential Oils } & \multicolumn{4}{|c|}{ Lethal doses(ml) } \\
\cline { 2 - 5 } & \multicolumn{3}{|c|}{ Adults $0.5 \mu 1$ /each adult and larva, respectively) } \\
\cline { 2 - 5 } & $\mathrm{LD}_{50}$ & $\mathrm{LD}_{95}$ & \multicolumn{2}{c|}{ Larvae } \\
\hline Thyme & 0.06 & 0.39 & 0.06 & LD $_{50}$ \\
\hline Basil & 0.11 & 1.16 & 0.12 & 0.64 \\
\hline Mint & 0.09 & 1.8 & 0.08 & 0.73 \\
\hline Garlic & 0.15 & 1.27 & 0.07 & 0.94 \\
\hline Chamomile & 0.14 & 0.70 & 0.08 & 0.54 \\
\hline Sesame & 0.32 & 2.2 & 0.16 & 0.81 \\
\hline
\end{tabular}

Detoxification enzymes assays:

The activities of five detoxification enzymes were investigated in treated last larval instar with essential oils by topical application of $\mathrm{LD}_{50}$ after 48 hours (Table 4). The $\alpha$-esterases and $\beta$-esterases activities were reduced significantly by, basil, garlic and sesame treatment than those of control. A significant reduction in activity of GST was also observed in larvae treated with basil, mint and sesame. A significant elevation in MFO activity was observed in case of larvae treated with chamomile oil when compared to the control. The activity of ALP was significantly high in case of larvae treated with sesame but its activity significantly reduced when larvae treated with chamomile. 
Table (4): Biochemical assays of detoxification enzymes activities of T. confusum last larval instar exposed to essential oils by topical application for $48 \mathrm{~h}$.

\begin{tabular}{|c|c|c|c|c|c|}
\hline \multirow[b]{2}{*}{ Essential Oils* } & \multicolumn{5}{|c|}{ Specific activity of detoxification enzymes } \\
\hline & $\begin{array}{c}\alpha \text {-esterases } \\
(\mu \mathrm{g} \alpha- \\
\text { naphthol/min/g. } \\
\text { b.wt. })\end{array}$ & $\begin{array}{c}\text { 及-esterases } \\
(\mu \mathrm{g} \beta \text { - } \\
\text { naphthol/min/g. } \\
\text { b.wt. })\end{array}$ & $\begin{array}{c}\text { MFO } \\
\text { ( } \mu \text { gp-nitro } \\
\text { phenol/min/g.b. } \\
\text { wt.) }\end{array}$ & $\begin{array}{c}\text { GTS } \\
(\mu \mathrm{mole} \\
\text { conjugated } / \mathrm{min} / \\
\text { g.b.wt. })\end{array}$ & $\begin{array}{c}\text { ALP } \\
\left(\mathrm{U} \times 10^{3} / \text { g.b.wt.) }\right.\end{array}$ \\
\hline Control & $5764 \pm 147^{\mathrm{a}}$ & $1544 \pm 140^{\mathrm{a}}$ & $116 \pm 3^{\mathrm{bc}}$ & $6577 \pm 227^{\text {ab }}$ & $2381 \pm 149^{b}$ \\
\hline Thyme & $5846 \pm 248^{\mathrm{a}}$ & $1330 \pm 103^{\mathrm{ab}}$ & $109 \pm 3^{\mathrm{c}}$ & $6303 \pm 186^{\mathrm{b}}$ & $2293 \pm 67^{b}$ \\
\hline Basil & $4327 \pm 352^{\mathrm{c}}$ & $1055 \pm 74^{\mathrm{c}}$ & $125 \pm 6^{\mathrm{ab}}$ & $4624 \pm 198^{\mathrm{d}}$ & $2255 \pm 141^{b}$ \\
\hline Mint & $5915 \pm 56^{\mathrm{a}}$ & $1359 \pm 60^{\mathrm{ab}}$ & $112 \pm 1^{\mathrm{c}}$ & $5792 \pm 119^{\mathrm{c}}$ & $2124 \pm 147^{\mathrm{bc}}$ \\
\hline Garlic & $5230 \pm 168^{\mathrm{b}}$ & $1225 \pm 88^{\mathrm{bc}}$ & $114 \pm 4^{\mathrm{c}}$ & $6989 \pm 134^{\mathrm{a}}$ & $2309 \pm 103^{b}$ \\
\hline Chamomile & $5716 \pm 118^{\mathrm{a}}$ & $1415 \pm 109^{\mathrm{ab}}$ & $134 \pm 3^{\mathrm{a}}$ & $6289 \pm 196^{\mathrm{b}}$ & $1891 \pm 120^{\mathrm{c}}$ \\
\hline Sesame & $5079 \pm 133^{\mathrm{b}}$ & $1230 \pm 57^{\mathrm{bc}}$ & $109 \pm 4^{\mathrm{c}}$ & $4765 \pm 194^{\mathrm{d}}$ & $2917 \pm 79^{a}$ \\
\hline
\end{tabular}

Means bearing different subscripts are significantly different at $(\mathrm{P}<0.01)$ ANOVA,Duncan's multiple range test.

* Newly moulted larvae were treated topically with $\mathrm{LD}_{50}$ of test essential oils for $48 \mathrm{hrs}$.

1 and $0.5 \mu 1$ of each concentration was applied topically on adult and larva, respectively

\section{DISCUSSION}

The obtained results in filter paper repellency assays of six essential oils against larvae and adults of $T$. confusum show that the test essential oils gave encouraging results against adults than larvae. All tested oils were highly repellent to the adult insect compared to the larvae. In the cup bioassay tests, the results did not completely overlap with those on filter papers. The moderate level of repellency was observed after exposure of adult to thyme oils. Other oils had significantly lower repellency effect on adults and larvae. The toxic and repellent effects of phytochemicals on $T$. confusum depend on several factors among which are the chemical composition of the crude oil and insect susceptibility (Casida, 1990). Crude oil extracts from plants contain components that increase their repellency and/or toxicity. The highly toxic and repellent effects of main constituents of these oils such as cymol, 1,8-cineole, terpineol and a-pinene have been demonstrated against $T$. confusum by other researchers (Ojimelukwe and Adler, 1999 and Tapondjou et al., 2005). Repellency could be due to the blend of oil constituents or to minor compounds present in oils and characterized by a significant biological activity (Cosimi, et al., 2009).

From our observations, both adults and larvae of $T$. confusum were highly resistant to fumigation and contact toxicity of tested essential oils; therefore we examined their toxic effects by topical application against larvae and adults. Arthur, 1998 and Fang et al. 2002 indicated that Tribolium spp. are classified among the least susceptible stored-product insect pests and often more difficult to kill than other stored product beetles, though the order of toxicity will often vary depending on the particular insecticide. Qiantai and Yongcheng (1998) found that camphor as the major isolate from essential oils of Cinnamomum cassia, Illicium verum and Cinnamomum camphora, had repellent effect, but not insecticidal activity against Tribolium castaneum.

On the basis of estimates of $\mathrm{LD}_{50}$ and $\mathrm{LD}_{95}$ values, larvae was significantly more susceptible than adults to tested essential oils The insecticidal activity of monoterpenes, the major component of essential oils, has been reported against stored products insects (Huang and Ho, 1998 and Garcì et al., 2005). Other constitutes of the test oils, such as limonene, camphor, 1, 8-cineole and $\mathrm{g}$-terpinene, possessed 
insecticidal effects against insects. Prates et al. (1998) found that terpenoids isolating from Brazilian flora had lethal effects on rice weevil caused by their influence on the respiratory and digestive systems. Lee et al., (2001) showed that menthone, limonene and linalool isolated from Mentha arvensis L. had toxic activity against rice weevil. Lee et al., (2003) showed that the plant monoterpenes cineole, fenchrone and pulegone in preliminary fumigant analyses successfully controlled the pest, and recommended these monoterpenes as suitable fumigants because of their high volatility, fumigant efficacy and safety. Monoterpenes act as neurotoxicants against different insect species. They have been shown to inhibit acetyl cholinesterase (AChE) isolated from different insect species (Grundy and Still, 1985 and Coats et al., 1991). Therefore, we suggest that the tested oils may cause insecticidal activity via one or more of these modes of actions.

The obtained results of detoxification enzymes reveal the different insecticidal effects of essential oils corresponding to different botanical families and mode of action on $T$. confusum larvae. The reduction in the activities of $\alpha$-esterases, $\beta$-esterases was showed by sesame, basil and garlic oils. Reduction in GST activity exhibited by basil, mint and sesame. Chamomile oil induced a reduction in ALP activity. Miao, (2002) and Zera, et al., (2004) stated that different stress, disease and toxic chemicals causes considerable decrease in the activity of ALP. Nathan et al., (2006) showed that treatment of rice plants with Melia azedarach Juss (Meliaceae) extracts decreased the activity level of ALP in Cnaphalcrocis medinalis (Guenee). By contrast, the activities of MFO and ALP were elevated by chamomile and sesame, respectively. Terriere, (1984) stated that such increase in enzyme activities has been shown to protect insects from insecticide poisoning as part of defense mechanism. Saleem et al., (1998) reported that the increased activities of esterase enzymes of $T$. castaneum adults after Cypermethrin treatment may be due to decreased body weight defend against insecticide stress conditions and or increase the energy production. An increase rate of detoxifying enzymes (hydrolases, transferases and oxygenases ) was responsible for imparting resistance in larvae to insecticides (Mohan and Gujar, 2003). Many studies have revealed the capacity of insect detoxification enzymes to be induced by xenobiotics and the relationship between elevated detoxifying enzyme levels and tolerance to chemical insecticides (Hemingway et al., 2004 and Feyereisen, 2005).

In conclusion the increase in MFO and ALP in larvae treated by chamomile and sesame, respectively suggest that these enzymes may be play a significant role in detoxification of chamomile and sesame The suppression of other enzymes ( $\alpha$ esterases, $\beta$-esterases, GST and ALP) indicated that these enzymes play no role in the detoxification of essential oils and may be increase the susceptibility of the confused flour beetle to the insecticides. Thus, it is likely that coexistence of other insecticides and these essential oils, may pose increased risks to this pest in stored products explored. Other studies are required to examine the combined effects of essential oils and other insecticides such as organophosphate or pyrethroid on the insect resistance.

However essential oils should be recognized as a possible alternative to chemical insecticides for stored-food pest control, especially in some market niches (Isman, 2000). If the problem of cost-effective commercial production can be solved, some of the compounds tested could find a place in IPM strategies, especially where the emphasis is on environmental and food safety and on replacing the more dangerous and toxic fumigants and insecticides (Rozman, et al., 2007).

Acknowledgment: 
The authors thank Professor Dr A.A Ebrahim the head of Entomology Department- Faculty of Science. Benha University for his help, encouragement and suggestion of the research point.

\section{REFERENCES}

Abbott, W.S. (1925). A method of computing the effectiveness of an insecticide. J. Econ. Entomol. 18: 265-267.

Aitken, A.D. (1975). Insect Travelers, I: Coleoptera, Technical Bulletin 31 HMSO, London.

Amos, T.G.; Wiliams, P.; Du Guesclin, P.B. and Schwarz, M. (1974). Compounds related to juvenile hormone: activity of selected terpenoids on $T$. castaneum and T. confusum. J. Econ. Entomol. 67: 474-476.

Arthur, F.H. (1998). Residual toxicity of cyfuthrin wettable powder against Tribolium confusum exposed for short time intervals on treated concrete. J. Stored Prod. Res. 34: 19-25.

Bull, D. L. (1981). Factors that influence tobacco budworm, Heliothis virescens, resistance to organophosphorous insecticides. Bull. Entomol. Soc. Amer 27: 193-197.

Casida, J.H. (1990). Pesticide mode of action, evidence for implications of a finite number of biochemical targets. In: Casida, J.E. (Ed.), Pesticides and Alternatives. Innovative Chemical and Biological Approaches to Pest Control, Elsevier, Amsterdam, pp. 11-22.

Cosimi, S.; Rossi, E.; Cioni, P.L. and Canale, A. (2009). Bioactivity and qualitative analysis of some essential oils from Mediterranean plants against storedproduct pests: Evaluation of repellency against Sitophilus zeamais Motschulsky, Cryptolestes ferrugineus (Stephens) and Tenebrio molitor (L.) J. Stored. Prod. Res xxx: 1-8.

Dou, W.; Shuang Wu.; Hassan, M. W. and Jin-Jun, W. (2009). Purification and biochemical characterization of glutathione S-transferases from three strains of Liposcelis bostrychophila Badonnel (Psocoptera: Liposcelididae): Implication of insecticide resistance. Pestic. Biochem. Physiol. 94: 10-14

Etebari, K. and Matindoost, L. (2004a). The study on effects of larval age and starvation stress on biochemical macromolecules abundance of haemolymph in silkworm Bombyx mori, in: Proceedings of the Sixteenth Iranian Plant Protection Congress, General Entomology Symposium, August 28-September 1, Univ. of Tabriz, Iran, pp. 435.

Etebari, K. and Matindoost, L. (2004b). Effects of hypervitaminosis of vitamin B3 on silkworm biology, J. Biosci. 29: 417-422.

Etebari, K.; Bizhannia, A.R.; Sorati, R. and Matindoost, L. (2007). Biochemical changes in haemolymph of silkworm larvae due to pyriproxyfen residue. Pestic. Biochem. Physiol. 88: 14-19

Fang, L.; Subramanyam, Bh. and Arthur, F.H. (2002). Effectiveness of spinosad on four classes of wheat against five stored product insects. J. Econ Entomol. 95: 640-650.

Feyereisen, R. (2005). Insect cytochrome P450. In: Gilbert, L.I., Iatrou, K., Gill, S. (Eds.), Comprehensive Insect Physiology, Biochemistry, Pharm. Mol. Biol. Elsevier, Amsterdam, pp. 1-77.

Finney, D.J. (1971). Statistical Method in Biological Assay $2^{\text {nd }}$ Edition. Griffin, London. 
Gacar, F. and Tasksn, V. (2009). Partial base sequence analysis of MdaE7 gene and ali-esterase enzyme activities in field collected populations of housefly (Musca domestica L.) from Mediterranean and Aegean Regions of Turkey. Pestic. Biochem. Physiol., 94: 86-92.

Garcìa, M.; Donadel, O. J.; Ardanaz, C. E.; Tonn, C. E. and Sosa, M. E. (2005) Toxic and repellent effects of Baccharis salicifolia essential oil on Tribolium castaneum. Pest Manag. Sci., 61: 612-618.

Grundy, D.L. and Still, C.C. (1985). Inhibition of acetylcholinesterases by pulegone1,2-epoxide. Pesticide Biochemistry and Physiology, 23: 383-388.

Habig, W.H.; Pabst, M.J. and Jakoby, W.B., (I974). Glutathione S- transferase the first enzymatic step in mercapturic acid formation. J. Biol. chem., 249: $7130-7139$.

Hansen, I.G. and Hodgson, E. (1971). Biochemical characteristics of insect microsomes. N-and o-demethylation . Biochem. Pharm., 20:1569-1578.

Hassanali, A.; Lwande, W.; Ole-Sitayo, N.; Moreka, L.; Nokoe, S. and Chapya, A. (1990). Weevil repellent constituents of Ocimum suave leaves and Eugenia caryophyllata cloves used as grain protectant in parts of eastern Africa. Discovery and Innovations, 2: 91-95.

Hemingway, J.; Hawkes, N.J.; McCarroll, L. and Ranson, H. (2004). The molecular basis of insecticide resistance in mosquitoes. Insect Biochem. Mol. Biol., 34: 653-665.

Huang, Y.; Hee, S. K. and Ho, S. H. (1998). Antifeedant and growth inhibitory effects of a-pinene on the stored-product insects, Tribolium castaneum (Herbst) and Sitophilus zeamais Motsch. Int. Pest Cont., 40: 18-20.

Isman, M.B. (2000). Plant essential oils for pest and disease management. Crop Prot., 12: 603-608.

Juliana, G. and Su, H.C.F. (1983). Laboratory studies on several plant materials as insect repellents for protection of cereal grains. J. Econ. Entomol., 76: 154-157.

Ketoh, G.K.; Koumaglo, H.K. and Glitho, I.A. (2005). Inhibition of Callosobruchus maculatus (F.) (Coleoptera: Bruchidae) development with essential oil extracted from Cymbopogon schoenanthus L. Spreng. (Poaceae), and the wasp Dinarmus basalis (Rondani) (Hymenoptera: Pteromalidae). J. Stored. Prod. Res., 41: 363-371.

Lee, S.; Peterson, C. J. and Coats, 1.R. (2003). Fumigation toxicity of monoterpenoids to several stored product insects. J. Stored. Prod. Res., 39: 77-85.

Lee, S. E.; Lee, R.H.; Choi, W.S.; Park, B.S.; Kim, J.G. and Campbell, B.C. (2001). Fumigant toxicity of volatile natural products from Korean spices and medicinal plants towards the rice weevil, Sitophilus oryzae (L). Pest Manage. Sci., 57: 548-553.

Miao, Y. (2002). Studies on the activity of the alkaline phosphatase in the midgut of infected silkworm, Bombyx mori L. J. Appl. Entomol., 126: 38-142.

McDonald, L.L.; Guy, R.H. and Speirs, R.D. (1970). Preliminary evaluation of new candidate materials as toxicants, repellents and attractants against stored product insects. Marketing Research Report. No 882. Agricultural Research Service, United State Department of Agriculture, Washington.

Mohan, S. and Fields, P.G. (2002). A simple technique to assess compounds that are repellent or attractive to stored-product insects. J. Stored Prod. Res., 38: 23-31. 
Mohan, M. and Gujar, G.T. (2003). Local variation in susceptibility of the diamondbackmoth, Plutella xylostella (Linnaeus) to insecticides and role of detoxification enzymes Crop Prot., 22: 495-504

Nathan, S. S. (2006). Effects of Melia azedarach on nutritional physiology and enzyme activities of the rice leaffolder Cnaphalocrocis medinalis (Guenée) (Lepidoptera: Pyralidae), Pestic. Biochem. Physiol., 84: 98-108.

Nathan, S. S.; Kalaivan, K. and. Chung, P. G. (2005). The effects of azadirachtin and nucleopolyhedrovirus on midgut enzymatic profile of Spodoptera litura Fab. (Lepidoptera: Noctuidae) Pestic. Biochem. Phys., 83 (1): 46-57.

Nishimura, H. (2001). Aroma constituents in plants and their repellent activities against mosquitoes. Aroma Res., 2: 257-267.

Ojimelukwe, P.C. and Adler, C. (1999). Potential of Zimtaldehyde, 4-allyl-anisol, linalool, terpineol and other phytochemicals for the control of confused flour beetle T. confusum J.D.V. J. Pestic. Sci., 72:81-86.

Powell, M.E.A. and Smith, M.J.H. (1954). The determination of serum acid and alkaline phosphatase activity with 4-aminoantipyrine. J. Clim. Pathol., 7: 245- 248.

Prates, H.T.; Santos, J.P.; Waquil, J.M.; Fabris, J.D. and Oliveira, A.B. (1998). The potential use of plant substances extracted from Brazilian flora to control stored grain pest. In: Zuxun, J., Quan, L., Yongsheng L., Xianchang, T., Lianghua, G. (Eds.), Proceedings of the $7^{\text {th }}$ International Conference on Stored prod. Prot., 14-19 Octo ber 1998, Beijing, China, vol. 1. Sichuan Publishing House of Sci. Technol., Chengdu, P.R. China, pp. 820-825.

Qiantai, L. and Yongcheng, S. (1998). Studies on effect of several plant materials against stored grain insects. In: J. Zuxun, L. Quan, L. Yongsheng, T. Xianchang and G. Lianghua, Editors, Proceedings of $7^{\text {th }}$ International Conference on Stored-prod. Prot., 14-19 October 1998, Beijing, China vol. 1, Sichuan Publishing House of Sci. Technol., Chengdu, P.R. China, pp. 836-844.

Rozman, V.; Kalinovica, I. and Korunic, Z. (2007). Toxicity of naturally occurring compounds of Lamiaceae and Lauraceae to three stored-product insects. J. Stored Prod. Res., 43: 349-355.

Saleem, M. A.; Shakoori, A. R. and Mantle, D. (1998). Macromolecular and enzymatic abnormaliries induced by a synthetic pyrthroid, Ripcord (Cypermthrin), in adult beetles of stord grain pest, castaneum (Herbst) (Coleoptera- Tenebrionidae). Arch. Ins. Biochem. Physiol., 39:144-145.

Shaaya, E.; Kostjukovski, M.; Eilberg, J. and Sukprakarn, C. (1997). Plant oils as fumigants and contact insecticides for the control of stored-product insects. J. Stored Prod. Res., 33: 7-15.

Shaaya, E.; Kostjukovski, M.; Eilberg, J. and Sukprakarn, C. (1997). Plant oils as fumigants and contact insecticides for the control of stored-product insects. J. Stored Prod. Res., 33: 7-15.

Tapondjou, A.L.; Adler, C.; Fontem, D.A.; Bouda, H. and Reichmuth, C. (2005). Bioactivities of cymol and essential oils of Cupressus sempervirens and Eucalyptus saligna against Sitophilus zeamais Motschulsky and $T$. confusum DuVal. J. Stored Prod. Res., 41: 91-102.

Terrier, L. C. (1984). Induction of detoxification enzymes in insects Annu. Rev. Entomol., 29:71-88.

Van Asperen, K. (I962). A study of house fly esterase by means of sensitive colourimetric method. J. Insect Physiol., 8:401-416. 
Wei, S.H.; Clark, A.G. and Syvanen, M. (2001).Identification and cloning of a key insecticide -metabolizing glutathione $S$ - transferase (MdGST-6A) from a hyper insecticide -resistant strain of the housefly Musca domestica, Insect Biochem. Mol. Biol., 31: 1145-1153.

White, N.D.G. (1995). Annual Costs Related to Stored-Product Pests in Canada (losses and preventive measures). Agriculture and Agri-Food Canada, Cereal Research Centre, Winnipeg

Zera, A. J. and Zhao, Z. (2004). Effect of a juvenile hormone analogue on lipid metabolism in a wing-polymorphic cricket: implications for the endocrinebiochemical bases of life-history trade-offs, Physiol. Biochem. Zool., 77: 255-266.

Zettler, J.L. (1991). Pesticide resistance in Tribolium castaneum and Tribolium confusum (Coleoptera: Tenebrionidae) from flour mills in the United States. J. Econ. Entomol., 84: 763-767.

Zhou, G.L., and Huang, J.L. (2002). Diversity and evolution of CYP6 family in insects. Entomol. Knowl., 39: 4246-251.

\section{ARABIC SUMMARY}

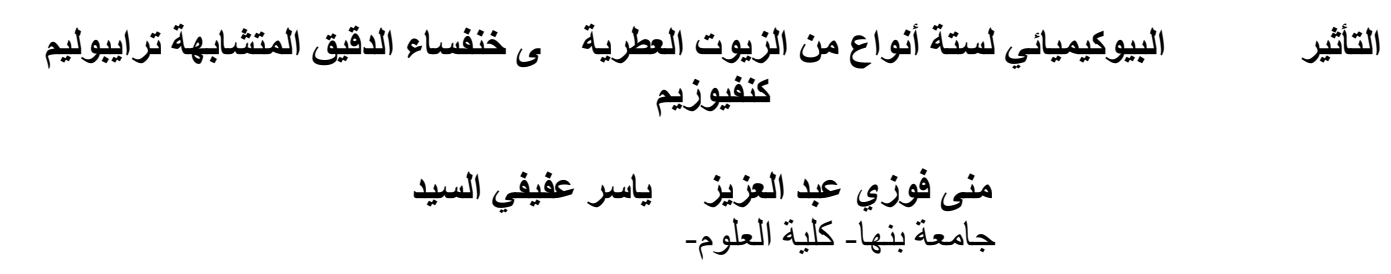

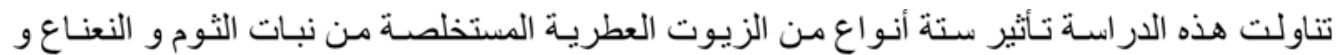

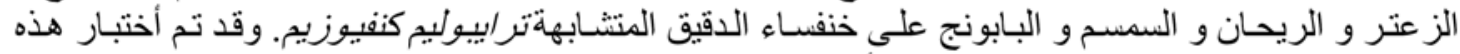

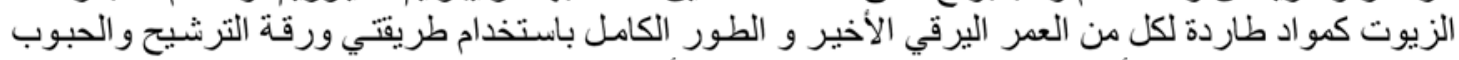

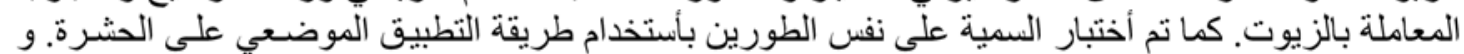

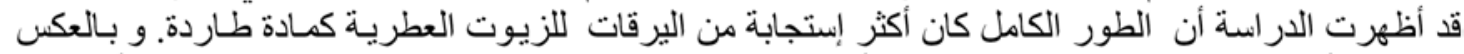

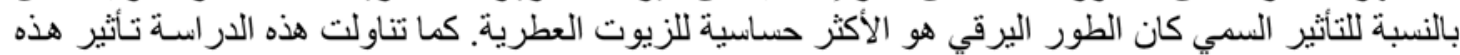

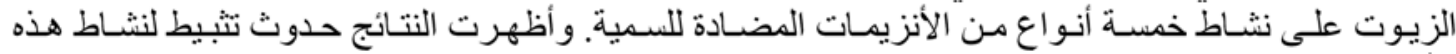

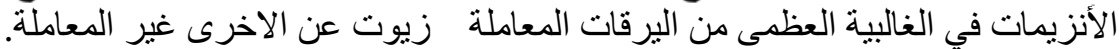

